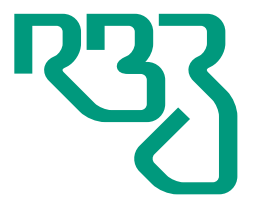

\section{Revista}

Brasileira de

Zootecnia

Brazilian Journal of Animal Science

ISSN 1806-9290

www.rbz.org.br

\title{
Replacing sodium bicarbonate with half amount of calcareous marine algae in the diet of beef cattle
}

\author{
Carlo Angelo Sgoifo Rossi ${ }^{1}$, Riccardo Compiani ${ }^{1}$, Gianluca Baldi ${ }^{*}$ (iD, \\ Stephen J. Taylor ${ }^{2}$ (iD, Federico Righi ${ }^{3}$ (iD), Marica Simoni ${ }^{3}$, Afro Quarantelli ${ }^{3}$ \\ ${ }^{1}$ University of Milan, Department of Health, Animal Science and Food Safety, Milan, Italy. \\ ${ }^{2}$ Celtic Sea Minerals, Cork, Ireland. \\ ${ }^{3}$ University of Parma, Department of Veterinary Science, Parma, Italy.
}

\begin{abstract}
*Corresponding author: gianluca.baldi87@gmail.com

Received: July 28, 2018

Accepted: April 16, 2019

How to cite: Sgoifo Rossi, C. A.; Compiani, R.; Baldi, G.; Taylor, S. J.; Righi, F.; Simoni, M. and Quarantelli, A. 2019. Replacing sodium bicarbonate with half amount of calcareous marine algae in the diet of beef cattle. Revista Brasileira de Zootecnia 48:e20180129. https://doi.org/10.1590/rbz4820180129
\end{abstract}

Copyright: This is an open access article distributed under the terms of the

Creative Commons Attribution License

(http://creativecommons.org/licenses/by/4.0/),

which permits unrestricted use, distribution, and reproduction in any medium, provided the original work is properly cited.

\begin{abstract}
This study evaluated the effects of feeding calcareous marine algae or sodium bicarbonate as rumen buffer on the performance, behaviour, in vitro diet digestibility, and meat quality of beef cattle. A total of 180 Charolaise bullocks $(536 \pm 38 \mathrm{~kg}$; $14 \pm 1$ months of age) were divided into two homogeneous groups and fed a diet with a mineral mix containing $40 \%$ sodium bicarbonate or $20 \%$ calcareous marine algae (CMA) for the entire fattening period (130 days). Of the in vivo and in vitro parameters evaluated, CMA supplementation improved average daily gain and feed conversion ratio and reduced the prevalence of bloat and lameness. Bullocks fed CMA tended to exhibit a calmer behaviour while in the pen. Supplementation with CMA improved rumen $\mathrm{pH}$ and in vitro digestion. Meat from bullocks fed CMA showed a lower $\mathrm{pH}$ and higher lightness and tenderness. The results suggest that CMA is more effective than sodium bicarbonate in buffering beef cattle, with a positive impact on growth performance, feed efficiency, health, and meat quality.
\end{abstract}

Keywords: acidosis, buffer, behavior, digestibility, lithothamnium, meat quality

\section{Introduction}

Acute and subacute rumen acidosis frequently affect intensively reared beef cattle, which are fed high-energy diets rich in highly fermentable carbohydrates. Acidosis reduces feed intake, growth performance, damages the gastrointestinal tissue, leads to inflammation due to lipopolysaccharides released from the death of gram-negative bacteria and predisposes cattle to diseases such as liver abscess and laminitis (Sgoifo Rossi and Compiani, 2016). Typical signs are rumen bloat, due to a high production and low absorption of volatile fatty acids (VFA), and loose manure due to a hyperosmotic environment in the gut.

Sodium bicarbonate (BIC) is commonly supplemented to buffer rumen $\mathrm{pH}$, although its buffering activity is reduced in condition of low rumen $\mathrm{pH}$ (5.5-5.8), as it has a pKa of 6.25 (Russell, 1998). In addition, BIC rapidly solubilizes into rumen fluid, with a fast but not long-lasting buffering activity. Because of this, a high amount is required to buffer the rumen $\mathrm{pH}$ of cattle fed high-energy diets $(0.7-1 \%$ of DM) (Krause, 2008). Giving a high amount of BIC in diets rich in phosphorous as those offered to beef cattle can increase urine $\mathrm{pH}$ above 6.8, increasing the risk of developing urolithiasis.

Calcareous marine algae (CMA), the skeletal of seaweed Lithothamnium calcareum harvested in the North Sea, could represent an alternative to BIC. Nearly $25 \%$ of CMA consists of calcium, in the form of calcium carbonate, a powerful buffer: bicarbonate ion $\left(\mathrm{HCO}_{3}{ }^{-}\right)$can react with one proton, while carbonate ion $\left(\mathrm{Co}_{3}{ }^{--}\right)$can react with two protons. Compared with limestone (100\% calcite), CMA has a specific mineral 
composition (65\% calcite, $12 \%$ vaterite, and $23 \%$ aragonite; Celtic Sea Minerals Ltd.), making it soluble at rumen pH (Cruywagen et al., 2015). Cruywagen et al. (2004) found an improvement in rumen pH by supplementing an increasing dose of CMA, from 0.125 to $1.2 \%$ dietary DM. Cruywagen et al. (2015) found that half a dose of CMA $(0.4 \%$ DM) was more effective than BIC $(0.8 \%$ DM) in buffering the rumen $\mathrm{pH}$ of dairy cows fed a high-energy diet. For beef cattle, supplemental calcium is beneficial to balance the calcium:phosphorous ratio and can improve meat tenderness by increasing muscle calcium, as calpain activity is calcium-dependent (e.g. Wheeler et al., 1997).

The objective of this study was to evaluate the effect of replacing BIC with half amount of CMA on performance, health, behaviour, rumen fermentation, in vitro digestibility, and meat quality of beef cattle.

\section{Material and Methods}

Procedures involving animals were carried out in compliance with EC Council Directive 2010/63. The study was carried out in a feedlot (latitude 45.6974, longitude 9.1376, and altitude $288 \mathrm{~m}$ ) in northern Italy. It involved 180 newly received Charolaise male cattle imported from France $(536 \pm 38 \mathrm{~kg}$; $14 \pm 1$ months of age), which were monitored throughout the fattening period (130 days).

At the arrival, cattle were weighed, and conformation was evaluated on a five-point scale (McKiernan, 2007). Cattle were treated for endo- and ectoparasites (Ivomec plus ${ }^{\circledR}$, Merial Italia SpA, MI, Italy) and vaccinated against respiratory disease viruses (Cattlemaster $4^{\circledR}$, Zoetis Italia S.r.l., Rome, Italy) on arrival and 21 days later as a booster. Cattle were blocked by weight and conformation and randomly allotted to slatted floor pens, each containing 10 animals, with a space allowance of $3.5 \mathrm{~m}^{2} /$ head, to obtain two homogeneous groups fed diets differing for the buffer included in the mineral-vitamin premix: BIC CMA. Animals were inspected twice a day by the farm veterinarian to evaluate the prevalence of diseases related to nutritional disorders - lameness and bloat. Bloat was defined as evident flank distention (score 1 to 3 of Min et al., 2005), while cattle were considered affected by lameness in the case of swollen joints and/or with deviation from normal walking (score 1 to 5 of Spercher et al., 1997) not caused by traumatic events.

Cattle were fed ad libitum a high-energy total mixed ration diet (Table 1) daily in the morning at $07.00 \mathrm{~h}$ and the feed pushed-up in the bunk at 12.00 and at $17.00 \mathrm{~h}$, with an estimated orts of 5-10\% based on farm data and previous experiments carried out in the same farm (Sgoifo Rossi et al., 2012). The amount of feed administered was recorded daily and once a week, before fresh feeding administration, and residual feed in the bunk was collected and weighed. The BIC and CMA diets of the two groups differed only in terms of the composition of mineral and vitamin mix.

The BIC mineral mix contained $400 \mathrm{~g} \cdot \mathrm{kg}^{-1}$ of sodium bicarbonate, which was replaced with $200 \mathrm{~g} \cdot \mathrm{kg}^{-1}$ of CMA (AcidBuf ${ }^{\circledast}$, Celtic Sea Minerals, Cork, Ireland) and adjusted in terms of the calcium and magnesium content (Table 2).

Animals were fed an adaptation diet for 25 days and then gradually adapted to the finisher diet (three days with $2 / 3$ adaptation diet and $1 / 3$ finisher diet, three days with $50 \%$ adaptation diet and $50 \%$ finisher diet, and three days with $1 / 3$ adaptation diet and $2 / 3$ finisher diet). Cattle were individually weighed at days $0,21,100$, and 130 , and the average daily gain (ADG) was calculated.

Behaviour during weighing was evaluated at the same intervals. A temperament score was assigned whilst cattle were restrained in the chute $(1=$ calm, no movement; $2=$ slightly restless; $3=$ squirming, occasional shaking of chute; $4=$ continuous vigorous movement of chute; $5=$ rearing, twisting, or violently struggling; Grandin, 1993), and exit ( 1 = walk, 2 = trot, 3 = run, and $4=$ jump; Lanier and Grandin, 2002). Behaviour was also evaluated in 2-h observation sessions at days 30, 60, 90, and 120, recording the number of mounting and fighting events (Cozzi et al., 2013).

Feed samples (200 g) were collected weekly and pooled for dry matter, crude protein, ether extract, starch, and ash determination, according to AOAC (1990); neutral-detergent fibre was determined according to Van Soest et al. (1991); the net energy content of the diet, as metabolisable energy, was calculated using the reference values for all feed ingredients reported by NRC (2000); and calcium, 
phosphorous, magnesium, and sodium were determined using ICP-MS methods (Agilent $7500 \mathrm{cx}$ ). As previously reported, orts were collected once a week to determine dry matter.

Faeces samples were collected from the rectus of one cattle/pen on days 21 and 100 to determine dry matter, crude protein, crude fat, ashes, starch (AOAC, 1990), and fibre fractions (Van Soest et al., 1991). At the same time, blood samples were collected from the jugular vein to determine plasma glucose, lactic acid, and serum urea. Plasma glucose was assessed by the glucose oxidase/peroxidase method (ILAB 300 plus, Instrumentation Laboratory, Milan). Plasma was obtained by centrifuging blood collected with EDTA tubes at $3500 \mathrm{rpm}$ for $10 \mathrm{~min}$ (Venosafe ${ }^{\circledR}$, Terumo). Plasma lactate was determined using a commercial kit (Lactate dry fast - Sentinel Diagnostics, Milan, Italy), while plasma urea concentration was determined by colorimetric assay (Technicon AAII Autoanalyser). From the same animals, $200 \mathrm{~mL}$ of rumen fluid was collected at the slaughterhouse and transported refrigerated to the laboratory for pH (Hanna Instruments, HI5522), $\mathrm{N}-\mathrm{NH}_{3}$, and lactic, acetic, propionic, and butyric acid determination. Gas were determined with high-performance liquid chromatography (Shimatzu, Kyoto, Japan).

To conduct a preliminary test on the applicability of rumen bolus for $\mathrm{pH}$ monitoring, a bolus fitted with a pH probe (Smaxtec, Graz, Austria) was inserted into the rumen of three cattle per group, assigned to different pens, at day 21, four days before the diet change, and the $\mathrm{pH}$ was monitored every $10 \mathrm{~min}$ for 35 days (data not statistically analysed; Figure 1 ). Particle size analysis of faeces was performed pooling

Table 1 - Experimental diets

\begin{tabular}{|c|c|c|c|c|}
\hline \multirow{2}{*}{ Feed ingredient $\left(\mathrm{g} \cdot \mathrm{kg}^{-1} \mathrm{DM}\right)$} & \multicolumn{2}{|c|}{ Adaptation diet } & \multicolumn{2}{|c|}{ Fattening diet } \\
\hline & $\mathrm{BIC}$ & CMA & $\mathrm{BIC}$ & CMA \\
\hline Mineral-vitamin with sodium bicarbonate (BIC) & 18.2 & - & 15.5 & - \\
\hline Mineral-vitamin with calcareous marine algae (CMA) & - & 18.2 & - & 15.5 \\
\hline Copra expeller & 25.9 & 25.9 & 22.1 & 22.1 \\
\hline Sunflower meal 28\% CP & 25.9 & 25.9 & 22.1 & 22.1 \\
\hline Rape cake & 17.3 & 17.3 & 14.7 & 14.7 \\
\hline Urea & 1.8 & 1.8 & 2.3 & 2.3 \\
\hline Slow-release non-protein nitrogen (Optigen ${ }^{\circledR}$ ) & 2.7 & 2.7 & 3.9 & 3.9 \\
\hline Corn meal & 250.5 & 250.5 & 413.7 & 413.7 \\
\hline Rice bran & 86.4 & 86.4 & 125.0 & 125.0 \\
\hline Wheat straw & 129.6 & 129.6 & 73.5 & 73.5 \\
\hline Corn silage, 35\% DM & 369.6 & 369.6 & 134.4 & 134.4 \\
\hline Fresh brewer grains, $25 \% \mathrm{DM}$ & 72.0 & 72.0 & 108.0 & 108.0 \\
\hline \multicolumn{5}{|l|}{ Nutritional values } \\
\hline Dry matter $\left(\mathrm{g} \cdot \mathrm{kg}^{-1}\right)$ & 503.3 & 503.6 & 623.6 & 624.0 \\
\hline Metabolisable energy $\left(\mathrm{MJ} \cdot \mathrm{kg}^{-1} \mathrm{DM}\right)^{1}$ & 10.18 & 10.18 & 11.71 & 11.76 \\
\hline Crude protein $\left(\mathrm{g} \cdot \mathrm{kg}^{-1} \mathrm{DM}\right)$ & 126.5 & 127.1 & 145.5 & 14.63 \\
\hline Neutral detergent fibre $\left(\mathrm{g} \cdot \mathrm{kg}^{-1} \mathrm{DM}\right)$ & 361.5 & 362.7 & 281.3 & 282.3 \\
\hline Starch $\left(\mathrm{g} \cdot \mathrm{kg}^{-1} \mathrm{DM}\right)$ & 321.7 & 322.2 & 424.5 & 425.2 \\
\hline $\mathrm{Ca}\left(\mathrm{g} \cdot \mathrm{kg}^{-1} \mathrm{DM}\right)$ & 7.3 & 7.6 & 7.7 & 7.8 \\
\hline$P\left(g \cdot \mathrm{kg}^{-1} \mathrm{DM}\right)$ & 4.5 & 4.5 & 5.4 & 5.4 \\
\hline $\mathrm{Mg}\left(\mathrm{g} \cdot \mathrm{kg}^{-1} \mathrm{DM}\right)$ & 2.9 & 2.9 & 2.4 & 2.4 \\
\hline
\end{tabular}

${ }^{1}$ Estimated from the reference values reported by NRC (2000). 
the faeces collected from the rectus from all the cattle in the pen using a Nasco Digestion Analyser (Nasco Fort Atkinson, WI, USA), comprised of three metal screens with a pore size of 4.76, 2.38, and $1.59 \mathrm{~mm}$, respectively. Approximately $500 \mathrm{~g}$ of faeces were collected and gently washed through the sieves until the water was clean. Orts was collected and dried for dry matter determination (AOAC, 1990), and distribution between sieves (\% of overall weight) was calculated. Given the impossibility of measuring individual feed intake, data were not statistically analysed.

Assuming an in vivo average dry matter intake of $10 \mathrm{~kg}$ and a daily administration of $200 \mathrm{~g} / \mathrm{head}$ of the studied mineral-vitamin premix containing CMA (20\% DM), the mineral-vitamin premix was pharmaceutically diluted in a representative sample of the basal diet at a concentration of $2 \%$, equal to a proportion of $0.5 \%$ of CMA. A similar dilution was performed for the BIC mineral-vitamin premix containing calcium carbonate $(53.5 \%)$ and sodium bicarbonate $(40.0 \%)$. In vitro neutral detergent fibre (NDF) digestibility (NDFD) was measured as detailed in Comino et al. (2014). Briefly,

Table 2 - Mineral and vitamin premixes

\begin{tabular}{lcc}
\hline Ingredient $\left(\mathrm{g} \cdot \mathrm{kg}^{-1}\right.$ as fed) & BIC & CMA \\
\hline Calcium carbonate & 535.0 & 400.0 \\
Calcareous marine algae (CMA; Acid Buf $\left.{ }^{\circledR}\right)$ & - & 200.0 \\
Sodium chloride & - & 100.0 \\
Sodium bicarbonate (BIC) & 400.0 & - \\
Magnesium oxide & 20.0 & - \\
Mycotoxin binder & 20.0 & 20.0 \\
Corn gluten feed & 15.0 & 270.0 \\
Vitamins & 5.0 & 5.0 \\
Micro minerals & 4.0 & 4.0 \\
Flavour & 0.5 & 0.5 \\
Live yeast & 0.5 & 0.5 \\
Ca $\left(\mathrm{g}^{\mathrm{k} g}{ }^{-1} \mathrm{DM}\right)$ & 224.0 & 223.3 \\
Mg $\left(\mathrm{g} \cdot \mathrm{kg}^{-1} \mathrm{DM}\right)$ & 14.5 & 14.4 \\
$\mathrm{Na}\left(\mathrm{g} \cdot \mathrm{kg}^{-1} \mathrm{DM}\right)$ & 82.7 & 40.8 \\
$\mathrm{P}\left(\mathrm{g} \cdot \mathrm{kg}^{-1} \mathrm{DM}\right)$ & 0.1 & 1.9 \\
\hline
\end{tabular}

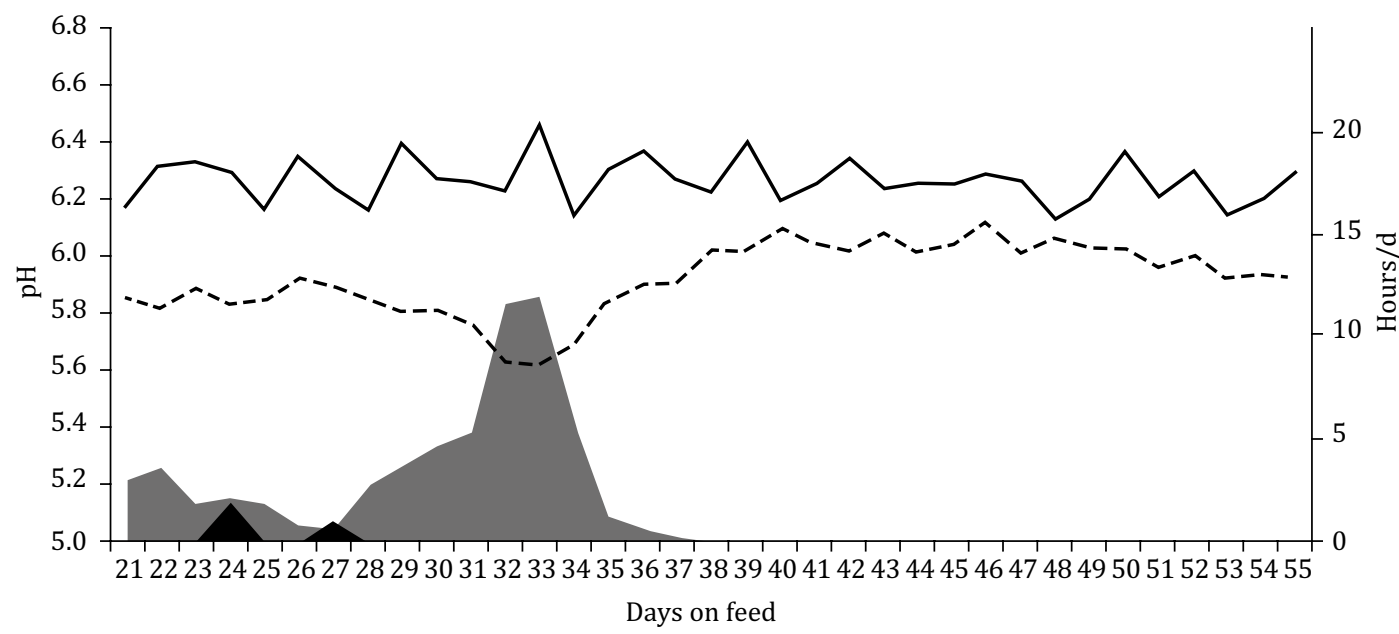

BIC $\mathrm{pH}<5.6 \square \mathrm{CMA} \mathrm{pH}<5.6 \cdot--\mathrm{BIC}$ average — CMA average

BIC - sodium bicarbonate; CMA - calcareous marine algae.

Figure 1 - Rumen pH monitored continuously with a bolus across diet transition (from day 25 to day 33; nine days) in three animals per group fed BIC or CMA diet. 
CMA and BIC total mixed ration subsamples were weighed $(0.5 \mathrm{~g})$ in 100-mL flasks (Schott Duran, Wertheim/Main, Germany).

To test the in vitro effect of CMA on fibre and dry matter digestibility (DMD), a medium, composed of a buffer, macromineral solution, micromineral solution, and resazurin as the redox state indicator of the system, was introduced into the flasks. A reducing solution was added to create an anaerobic environment. The flasks were then placed into a water bath and purged with $\mathrm{CO}_{2}$ to obtain complete anaerobiosis. Rumen fluid was collected from a dry cow fed $2 \mathrm{~kg}$ of concentrate per day and given ad libitum access to grass/alfalfa mixed hay (55\% NDF; $14 \%$ CP). Rumen fluid was then stirred, filtered through four layers of cheesecloth, and inoculated into each flask to start the fermentation process.

Subsamples were incubated for intervals of $4,8,24$, and $48 \mathrm{~h}$ at $39.5^{\circ} \mathrm{C}$. Two analytical replicates were incubated per treatment for each incubation time. After incubation, each subsample was filtered through crucibles (Robu Glass Filter-ROBU H3, Borosilicate 3.3, 30 mL-Por. 2, Hattert, Germany), rinsed three times with boiling water, dried overnight at $105{ }^{\circ} \mathrm{C}$, and weighed for DMD determination. The liquid derived from the first filtration process was collected and analysed for volatile fatty acids and lactic acid content by high-performance liquid chromatography (HPLC). Amylase-treated NDF (aNDF) was then determined on each subsample DM residue using a raw fibre extractor (FIWE, VELP Scientifica, Usmate Velate, Italy).

Each crucible containing the DM residue was connected with the raw fibre extractor tubes, and the residue was boiled for $1 \mathrm{~h}$ in a neutral detergent solution that included heat-stable amylase (Number A3306; Sigma Chemical Co.) and filtered through the same crucibles. The neutral detergent residuals were then rinsed three times with boiling water, dried overnight at $103{ }^{\circ} \mathrm{C}$, and weighed to calculate NDFD at 4, 8, 24, and $48 \mathrm{~h}$. Acid detergent fibre (ADF) was sequentially determined on NDF residues obtained at the different incubation times for the determination of ADF digestibility (ADFD) (Van Soest, 1991).

Analyses of HPLC were performed in duplicate for each treatment and interval. The lactic and monocarboxylic acids (acetic, propionic, and butyric acids) were determined by HPLC in the acid extract from rumen fluid using an Aminex HPX-87H strong cation exchange resin column at $41{ }^{\circ} \mathrm{C}$, $0.0025 \mathrm{M} \mathrm{H}_{2} \mathrm{SO}_{4}$ mobile phase, and ultraviolet detector at $210 \mathrm{~nm}$ as described in Canale et al. (1984).

Cold carcass weight (as $98 \%$ of hot carcass weight) was recorded, and dressing percentage calculated. SEUROP conformation (converted on a six-point scale: $S=6, E=5, U=4, R=3,0=2, P=1$ ) and fattening score (1-5) were assessed by a professional assessor (EU, 2006. Council Regulation EC 1183/2006).

At $24 \mathrm{~h}$ post-mortem, carcass $\mathrm{pH}$ was measured on three cattle per pen on longissimus dorsi between the 5th and 6th ribs (HI 98150, HANNA Instruments Inc., Woonsocket, RI, USA), and $5 \mathrm{~cm}$-thick longissimus dorsi samples were then taken in the same position. Before being vacuum-packaged, two thin slices were removed perpendicular to the muscle fibres (nearly $10 \mathrm{~g}$ ) for calcium titration and chemical composition (dry matter, ether extract, crude protein, and ash).

Muscle calcium was determined with inductive coupled plasma-optical emission spectrometry (ICP-OES), while chemical composition was determined on samples trimmed from external fat and connective tissue and homogenized for $30 \mathrm{~s}$ according to AOAC (1990). Samples were then weighed, vacuum-packaged, and stored at $2 \pm 1{ }^{\circ} \mathrm{C}$ for 6 days.

At the end of the established ageing period, samples were unpackaged, blotted dry, and reweighed to evaluate purge loss. At the opening, a thin slice perpendicular to the muscle fibre was removed to create a fresh cut surface, which was allowed to bloom for $1 \mathrm{~h}$ at refrigerated temperature in a dark room. The instrumental colour was then assessed with a chromameter (Minolta Camera, Co., Osaka, Japan) calibrated on the CIE L* $\mathrm{a}^{*} \mathrm{~b} *$ colour space (Calibration Plate 21533131 Y 93.4 x 0.3456 y 0.3321, Minolta Cameras Co., Osaka, Japan), illuminant D65 and view angle 10. Samples were blotted dry before being weighed. After colour measurement, $3 \mathrm{~cm}$ thick samples were weighed, cooked in a water bath at $75^{\circ} \mathrm{C}$ core temperature (monitored with a temperature meter Hanna Instruments HI98840 temperature meter) and refrigerated overnight. On the subsequent day, samples were weighed again to measure 
cooking loss. After cooking loss determination, six cylindrical cores, $1.27 \mathrm{~cm}$ in diameter, parallel to the fibre orientation, were obtained and used for shear force evaluation, using a Warner-Bratzler shear force texture analyser (model 4466; Instron Corp., Canton, MA). Peak force $\left(\mathrm{kg}^{\cdot} \mathrm{cm}^{2-1}\right)$ was recorded.

Statistical analysis was performed with SAS software (Statistical Analysis System, version 9.4) with the REML procedure (PROC MIXED). For body weight, ADG, ADFI, FCR, behaviour in pen (average mounting/fighting events per pen), and faeces particle size, pen was considered as the experimental unit, and the model accounted for the fixed effects of dietary treatment and time (not for faeces particle size) and the random effect of the pen within treatment and time. The model used was:

$$
\mathrm{Y}_{\mathrm{ijk}}=\mu+\alpha_{\mathrm{i}}+\beta_{\mathrm{j}}+\mathrm{c}_{\mathrm{k}}+\alpha_{\mathrm{i}} \beta_{\mathrm{j}}+\mathrm{e}_{\mathrm{ij} \mathrm{j}^{\prime}}
$$

in which $Y_{i j k}=$ observation of the pen $k$ given treatment $i$ at period $j, \alpha_{\mathrm{i}}=$ fixed effect of the $i$-th treatment, $\beta_{\mathrm{j}}=$ fixed effect of the $j$-th time (when relevant), $\mathrm{c}_{\mathrm{k}}=$ the random effect of the $k$-th pen, $\alpha_{\mathrm{i}} \beta_{\mathrm{j}}=$ interaction between $i$-th treatment at $j$-th time, and $\mathrm{e}_{\mathrm{ijk}}=$ residual error of the model.

For temperament parameters (average temperament score during restraining and exiting the chute), blood (glucose, urea, and lactic acid), and faeces data (dry matter, crude protein, starch, NDF, ADF, acid detergent lignin ( $\mathrm{ADL}$ ), cellulose, and hemicellulose), the animal was considered the experimental unit and the model accounted for the fixed effects of dietary treatment and time and random effect of animal within treatment and time. Repeated measures accounted for the effects of dietary treatment, sampling time, and their interaction. The model used was:

$$
Y_{i j \mathrm{k}}=\mu+\alpha_{\mathrm{i}}+\beta_{\mathrm{j}}+\mathrm{c}_{\mathrm{k}}+\alpha_{\mathrm{i}} \beta_{\mathrm{j}}+\mathrm{e}_{\mathrm{ij} \mathrm{k}^{\prime}}
$$

in which $\mathrm{Y}_{\mathrm{ijk}}=$ observation of the animal $k$ given treatment $i$ at period $j, \alpha_{\mathrm{i}}=$ fixed effect of the $i$-th treatment, $\beta_{\mathrm{j}}=$ fixed effect of the $j$-th time (when relevant), $\mathrm{c}_{\mathrm{k}}=$ the random effect of the $k$-th animal, $\alpha_{\mathrm{i}} \beta_{\mathrm{j}}=$ interaction between $i$-th treatment at $j$-th time, and $\mathrm{e}_{\mathrm{ij \textrm {k }}}=$ residual error of the model.

Meat quality data were analysed with one-way ANOVA, accounting for the fixed effect of dietary treatment and random effect of the animal. The model used was:

$$
\mathrm{Y}_{\mathrm{ij}}=\mu+\alpha_{\mathrm{i}}+\beta_{\mathrm{k}}+\mathrm{e}_{\mathrm{ik}}
$$

in which $Y_{\mathrm{ij}}=$ observation of the animal $k$ given treatment $i, \alpha_{\mathrm{i}}=$ fixed effect of the $i$-th treatment, $\beta_{\mathrm{k}}=$ the random effect of the $k$-th animal, and $\mathrm{e}_{\mathrm{ik}}=$ residual error of the model.

Data from in vitro analyses were analysed with the REML procedure accounting for the fixed effect of dietary treatment and intervals of fluid collection and random effects of replicates. The model used was:

$$
\mathrm{Y}_{\mathrm{ijk}}=\mu+\alpha_{\mathrm{i}}+\beta_{\mathrm{j}}+\alpha_{\mathrm{i}} \beta_{\mathrm{j}}+\mathrm{c}_{\mathrm{k}}+\mathrm{e}_{\mathrm{ij} \mathrm{j}^{\prime}}
$$

in which $Y_{\mathrm{ijk}}=$ observation of the replicate $k$ given treatment $i$ at interval $j, \alpha_{\mathrm{i}}=$ fixed effect of the $i$-th treatment, $\beta_{\mathrm{j}}=$ fixed effect of the $j$-th interval, $\alpha_{\mathrm{i}} \beta_{\mathrm{j}}=$ interaction between $i$-th treatment at $j$-th interval, $\mathrm{c}_{\mathrm{k}}=$ the random effect of the $k$-th replicate, and $\mathrm{e}_{\mathrm{ij \textrm {k }}}=$ residual error of the model.

The significance of the differences in prevalence of bloat and lameness between groups was tested with the chi-square test. Significance was set for $\mathrm{P} \leq 0.05$, while $\mathrm{P} \leq 0.1$ was discussed as tendency.

\section{Results}

Considering the overall study period, CMA improved ADG ( $\mathrm{P}=0.02)$, although the differences in body weight were not significant. The average daily feed intake (ADFI) did not differ between groups. The higher ADG coupled with the similar ADFI improved FCR ( $\mathrm{P}=0.03$ ) (Table 3$)$.

Calcareous marine algae reduced the prevalence of acidosis-related diseases $(P=0.05$; Table 4): 1 vs 0 bloat and 5 vs 1 lameness were recorded in the group fed BIC compared with the group fed CMA. On average, cattle of both groups were almost calm or slightly restless in the chute and exiting from it, walking or trotting, highlighting a good interaction with humans and with new circumstances (Table 4). Dietary treatment did not affect behaviour. Cattle tended to be quieter during restraining $(\mathrm{P}<0.01)$ and 
exiting the chute $(\mathrm{P}=0.06)$, approaching the end of the fattening cycle. Regarding pen behaviour, cattle that received CMA instead of BIC, overall tended to exhibit a lower number of fighting or mounting events ( $\mathrm{P}=0.09)$, while an interactive effect of time and treatment was not observed. Blood parameters were not affected by the dietary treatment (Table 5).

The group fed CMA showed higher fine particles of undigested fraction $(\mathrm{P}<0.01)$, suggesting a better fibre digestion. Lower faecal NDF $(\mathrm{P}=0.09)$ and hemicellulose $(\mathrm{P}<0.01)$ and higher ADF $(\mathrm{P}<0.01)$ and $\mathrm{ADL}(\mathrm{P}=0.02)$ were recorded in the group fed CMA, while no differences were evident for $\mathrm{DM}, \mathrm{CP}$, and starch (Table 6).

Table 3 - Growth performance parameters (expressed as mean and standard error of the means) of cattle fed sodium bicarbonate (BIC) or calcareous marine algae (CMA) diet $(\mathrm{n}=180)$

\begin{tabular}{|c|c|c|c|c|c|c|}
\hline & BIC & CMA & SEM & P diet & P day & $\mathrm{P}$ diet $\times$ day \\
\hline \multicolumn{7}{|c|}{ Weight (kg) } \\
\hline Day 0 & 539 & 533 & 7.62 & \multirow{4}{*}{ ns } & \multirow{4}{*}{$<0.01$} & \multirow{4}{*}{ ns } \\
\hline Day 21 & 567 & 562 & 7.62 & & & \\
\hline Day 100 & 693 & 696 & 7.62 & & & \\
\hline Day 130 & 729 & 734 & 7.62 & & & \\
\hline \multicolumn{7}{|c|}{ Average daily gain $(\mathrm{kg} / \mathrm{d})$} \\
\hline $0-21$ & 1.30 & 1.38 & 0.04 & & & \\
\hline $0-100$ & 1.53 & 1.63 & 0.04 & 0.02 & $<0.01$ & ns \\
\hline $0-130$ & $1.46 \mathrm{a}$ & $1.54 \mathrm{~b}$ & 0.03 & & & \\
\hline \multicolumn{7}{|c|}{ Average daily feed intake (kg DM/d) } \\
\hline $0-21$ & 10.32 & 10.31 & 0.10 & & & \\
\hline $0-100$ & 11.30 & 11.31 & 0.11 & ns & $<0.01$ & ns \\
\hline $0-130$ & 11.51 & 11.52 & 0.11 & & & \\
\hline \multicolumn{7}{|c|}{ Feed conversion ratio (kg DM/kg) } \\
\hline $0-21$ & 8.48 & 7.65 & 0.25 & & & \\
\hline $0-100$ & 7.86 & 7.19 & 0.25 & 0.03 & $<0.01$ & ns \\
\hline $0-130$ & $8.18 \mathrm{a}$ & $7.66 \mathrm{~b}$ & 0.13 & & & \\
\hline
\end{tabular}

$\mathrm{a}, \mathrm{b}-\mathrm{P}<0.05$.

Table 4 - Health, temperament, and behaviour parameters (expressed as mean and standard error of the means) of beef cattle fed sodium bicarbonate (BIC) or calcareous marine algae (CMA) diet ( $n=180)$

\begin{tabular}{|c|c|c|c|c|c|c|}
\hline & $\mathrm{BIC}$ & CMA & SEM & $\mathrm{P}$ diet & P day & $P$ diet $\times$ day \\
\hline Morbidity, \% (n) & $6.67(6)$ & $1.11(1)$ & & 0.05 & & \\
\hline \multicolumn{7}{|c|}{ Average temperament score while restrained in the chute ${ }^{1}$} \\
\hline Day 0 & 1.32 & 1.27 & 0.06 & \multirow{4}{*}{ ns } & \multirow{4}{*}{$<0.01$} & \multirow{4}{*}{ ns } \\
\hline Day 21 & 1.26 & 1.21 & 0.05 & & & \\
\hline Day 100 & 1.20 & 1.14 & 0.04 & & & \\
\hline Day 130 & 1.22 & 1.13 & 0.04 & & & \\
\hline \multicolumn{7}{|c|}{ Average temperament score exiting the chute ${ }^{2}$} \\
\hline Day 0 & 1.30 & 1.25 & 0.06 & \multirow{4}{*}{ ns } & \multirow{4}{*}{0.06} & \multirow{4}{*}{ ns } \\
\hline Day 21 & 1.19 & 1.18 & 0.04 & & & \\
\hline Day 100 & 1.20 & 1.19 & 0.04 & & & \\
\hline Day 130 & 1.27 & 1.21 & 0.05 & & & \\
\hline \multicolumn{7}{|c|}{ Average mounting or fighting events per pen } \\
\hline Day 30, \% (n) & 0.44 & 0.11 & 0.14 & \multirow{4}{*}{0.09} & \multirow{4}{*}{ ns } & \multirow{4}{*}{ ns } \\
\hline Day 60, \% (n) & 0.56 & 0.11 & 0.19 & & & \\
\hline Day $90, \%(n)$ & 0.67 & 0.22 & 0.31 & & & \\
\hline Day $120, \%(n)$ & 0.7 & 0.24 & 0.25 & & & \\
\hline
\end{tabular}

${ }^{1} 1$ = calm, no movement; 2 = slightly restless; 3 = squirming, occasional shaking of chute; 4 = continuous vigorous movement of chute; $5=$ rearing, twisting, or violently struggling.

$21=$ walk; 2 = trot; 3 = run; 4 = jump. 
Table 5 - Blood parameters (expressed as mean and standard error of the means) in beef cattle fed sodium bicarbonate (BIC) or calcareous marine algae (CMA) diet ( $\mathrm{n}=18)$

\begin{tabular}{|c|c|c|c|c|c|c|}
\hline & BIC & CMA & SEM & $\mathrm{P}$ diet & $\mathrm{P}$ day & $P$ diet $\times$ day \\
\hline Day 21 & 96.88 & 99.75 & 5.72 & \multirow{2}{*}{ ns } & \multirow{2}{*}{$<0.01$} & \multirow{2}{*}{ ns } \\
\hline Day 100 & 68.25 & 70.62 & 2.85 & & & \\
\hline \multicolumn{7}{|c|}{ Serum urea $\left(\mathrm{mg} \cdot \mathrm{dL}^{-1}\right)$} \\
\hline Day 21 & 31.38 & 32.50 & 2.14 & ns & $<0.01$ & ns \\
\hline \multicolumn{7}{|c|}{ Lactic acid $\left(\mathrm{mg} \cdot \mathrm{dL}^{-1}\right)$} \\
\hline Day 21 & 32.45 & 34.75 & 3.52 & \multirow{2}{*}{ ns } & \multirow{2}{*}{$<0.01$} & \multirow{2}{*}{ ns } \\
\hline Day 100 & 22.96 & 24.90 & 0.96 & & & \\
\hline
\end{tabular}

Table 6 - Faces composition (expressed as mean and standard error of the means) of cattle fed sodium bicarbonate (BIC) or calcareous marine algae (CMA) diet $(n=18)$

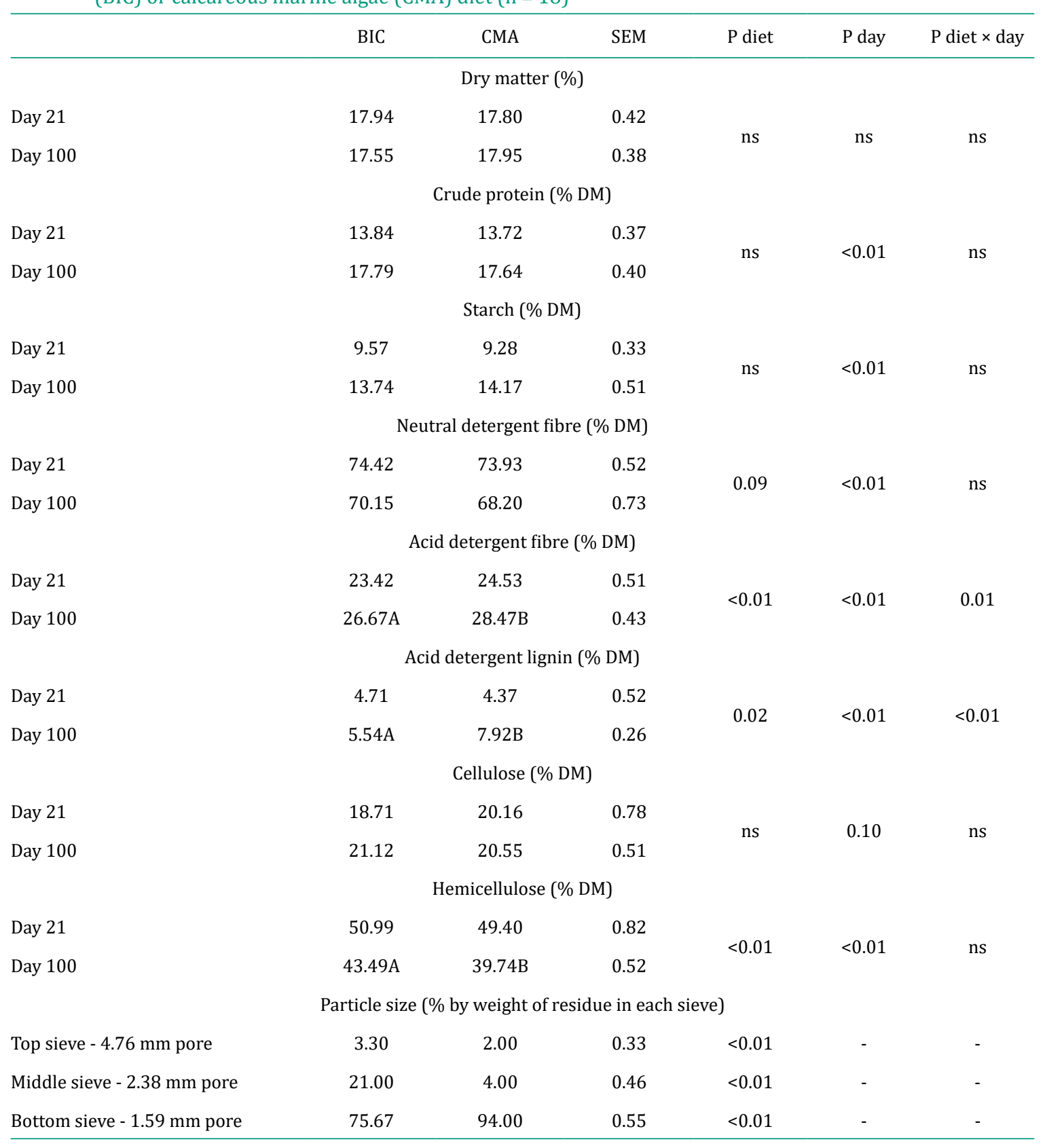

A,B $-\mathrm{P}<0.01$. 
The results were in line with findings from in vitro data (Table 7). Overall, CMA administration improved $\mathrm{NDF}(\mathrm{P}<0.01), \mathrm{ADF}(\mathrm{P}<0.01)$, and total dry matter $(\mathrm{P}=0.03)$ in vitro digestion. As expected, fibre and total dry matter digestion improved with time $(\mathrm{P}<0.001)$, without an interactive effect between treatment and sampling time. Treatment did not affect in vitro VFA production, while there was an increase in VFA production during incubation for acetic, propionic, and butyric acids, with lactate showing the opposite trend (Table 8).

Regarding rumen fluid collected at slaughter (Table 9), the group fed CMA showed a higher $\mathrm{pH}(\mathrm{P}<0.01)$ and butyric acid $(\mathrm{P}<0.01)$. Cattle fed $\mathrm{CMA}$ showed higher rumen $\mathrm{pH}$ and spend less time with rumen $\mathrm{pH}$ below 5.6. Indeed, in the first 15 days of diet change, monitored cattle in group fed BIC spent on average 4:09 h/day with $\mathrm{pH}<5.6$, while those fed CMA spent only 00:12 h/day with $\mathrm{pH}<5.6$.

No differences were detected for dressing percentage, carcass weight, conformation, and fat cover score (Table 10). Similarly, dietary treatment did not affect the chemical composition of the meat, muscle calcium, purge, and cooking loss. Conversely, meat from cattle fed CMA was characterised by a lower pH $(\mathrm{P}<0.05)$, higher lightness $(\mathrm{P}<0.05)$ and yellowness $(\mathrm{P}<0.05)$, and lower shear force $(\mathrm{P}<0.05)$. No abnormal $\mathrm{pH}$, above 5.8 , was recorded.

Table 7 - In vitro DMD, NDFD, and ADFD on ruminal fluid of cattle fed sodium bicarbonate (BIC) or calcareous marine (CMA) diet (expressed as mean and standard error of the means)

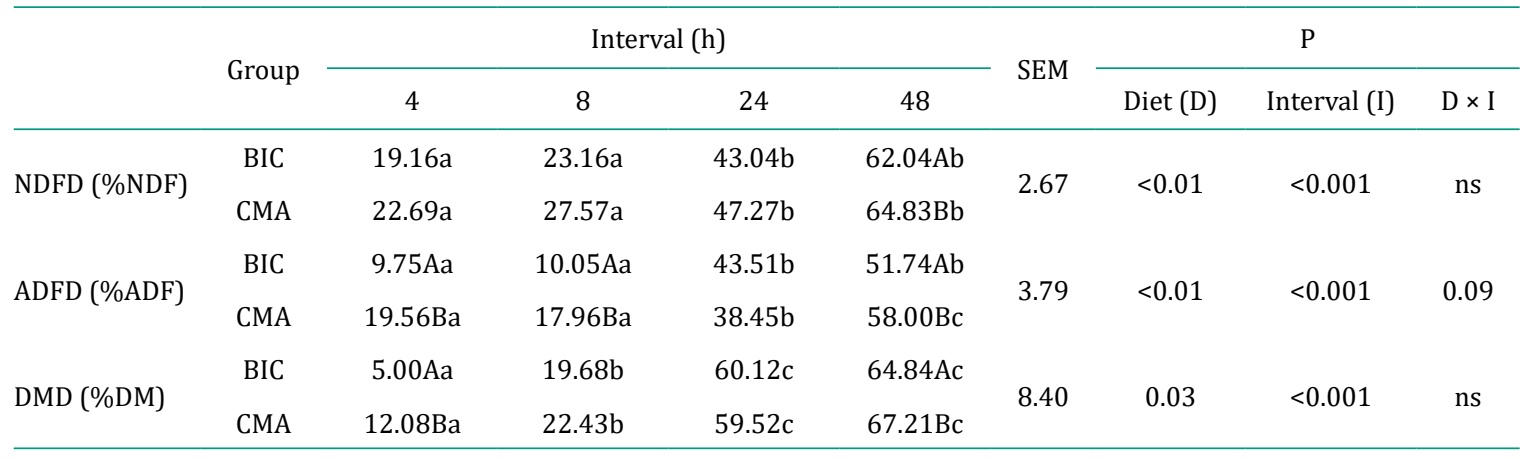

NDFD - neutral detergent fibre digestibility; ADFD - acid detergent fibre digestibility; DMD - dry matter digestibility. a,b,c $-\mathrm{P}<0.05$.

$\mathrm{A}, \mathrm{B}, \mathrm{C}-\mathrm{P}<0.01$.

Table 8 - In vitro volatile fatty acid and lactate production of ruminal fluid of cattle fed sodium bicarbonate (BIC) or calcareous marine (CMA) diet (expressed as mean and standard error of the means)

\begin{tabular}{|c|c|c|c|c|c|c|c|c|c|}
\hline \multirow{2}{*}{ VFA } & \multirow{2}{*}{ Group } & \multicolumn{4}{|c|}{ Interval (h) } & \multirow{2}{*}{ SEM } & \multicolumn{3}{|c|}{$\mathrm{P}$} \\
\hline & & 4 & 8 & 24 & 48 & & $\operatorname{Diet}(\mathrm{D})$ & Interval (I) & $\mathrm{D} \times \mathrm{I}$ \\
\hline \multirow{2}{*}{ Lactic acid (mg/dL) } & BIC & $54.79 c$ & $63.98 c$ & $20.70 b$ & $7.00 \mathrm{a}$ & \multirow{2}{*}{5.97} & \multirow{2}{*}{ ns } & \multirow{2}{*}{0.001} & \multirow{2}{*}{ ns } \\
\hline & CMA & $51.14 \mathrm{c}$ & $32.41 c$ & $19.42 b$ & $6.28 \mathrm{a}$ & & & & \\
\hline \multirow{2}{*}{ Acetic acid (mg/dL) } & $\mathrm{BIC}$ & $175.04 \mathrm{a}$ & 238.31ab & $281.87 b$ & $305.87 \mathrm{~b}$ & \multirow{2}{*}{17.26} & \multirow{2}{*}{ ns } & \multirow{2}{*}{$<0.001$} & \multirow{2}{*}{ ns } \\
\hline & CMA & $174.56 \mathrm{a}$ & 229.49ab & $307.99 b$ & $349.45 b$ & & & & \\
\hline \multirow{2}{*}{ Propionic acid (mg/dL) } & $\mathrm{BIC}$ & $104.61 \mathrm{a}$ & 128.95abc & $155.52 \mathrm{c}$ & $130.23 b$ & \multirow{2}{*}{6.43} & \multirow{2}{*}{ ns } & \multirow{2}{*}{0.005} & \multirow{2}{*}{ ns } \\
\hline & CMA & $109.48 a$ & $102.52 b$ & $163.49 b$ & 142.89ab & & & & \\
\hline \multirow{2}{*}{ Butyric acid (mg/dL) } & BIC & $35.62 \mathrm{a}$ & $99.58 b$ & $94.55 b$ & $95.26 \mathrm{~b}$ & \multirow{2}{*}{8.98} & \multirow{2}{*}{ ns } & \multirow{2}{*}{0.002} & \multirow{2}{*}{ ns } \\
\hline & CMA & $48.59 \mathrm{a}$ & $52.63 a$ & $114.52 b$ & $112.62 b$ & & & & \\
\hline
\end{tabular}

a,b,c $-\mathrm{P}<0.05$.

Table 9 - Volatile fatty acid, lactic acid, and pH (expressed as mean and standard error of the means) of rumen fluid of cattle fed sodium bicarbonate (BIC) or calcareous marine (CMA) diet collected at slaughterhouse $(\mathrm{n}=18)$

\begin{tabular}{lcccc}
\hline & BIC & CMA & SEM & P \\
\hline Lactic acid (mg/100 g) & 1.91 & 1.26 & 0.42 & $\mathrm{~ns}$ \\
Acetic acid (mg/100 g) & 67.33 & 69.28 & 15.40 & $\mathrm{~ns}$ \\
Propionic acid (mg/100 g) & 17.50 & 17.56 & 1.23 & $\mathrm{~ns}$ \\
Butyric acid (mg/100 g) & 12.45 & 10.88 & 0.75 & $<0.01$ \\
$\mathrm{pH}$ & 5.62 & 6.25 & 0.06 & $<0.01$ \\
\hline
\end{tabular}


Table 10 - Carcass traits $(n=180)$ and meat quality $(n=54)$ of beef cattle fed sodium bicarbonate (BIC) or calcareous marine (CMA) diet (expressed as mean and standard error of the means)

\begin{tabular}{|c|c|c|c|c|}
\hline & $\mathrm{BIC}$ & CMA & SEM & $\mathrm{P}$ \\
\hline \multicolumn{5}{|c|}{ Carcass trait } \\
\hline Carcass weight (kg) & 436 & 441 & 3.01 & ns \\
\hline Dressing percentage (\%) & 59.76 & 60.02 & 0.77 & \multirow[t]{2}{*}{ ns } \\
\hline Conformation E, \% (n) & $60.00(54)$ & $57.78(52)$ & - & \\
\hline Conformation U, \% (n) & $38.89(35)$ & $42.22(38)$ & - & ns \\
\hline Conformation R, \% (n) & $1.11(1)$ & $0.00(0)$ & - & \multirow{4}{*}{ ns } \\
\hline Fat cover $2, \%(n)$ & $71.11(64)$ & $72.22(65)$ & - & \\
\hline \multirow[t]{2}{*}{ Fat cover $3, \%(n)$} & $28.89(26)$ & $27.78(25)$ & - & \\
\hline & & Colour & & \\
\hline $\mathrm{L}$ & 44.20 & 47.62 & 0.85 & $<0.01$ \\
\hline$a^{*}$ & 19.92 & 21.34 & 0.87 & ns \\
\hline $\mathrm{b}^{*}$ & 11.97 & 13.29 & 0.39 & 0.02 \\
\hline Hue & 31.20 & 32.12 & 0.77 & ns \\
\hline \multirow[t]{2}{*}{ Chroma } & 23.40 & 25.43 & 0.95 & ns \\
\hline & \multicolumn{3}{|c|}{ Chemical composition } & \\
\hline Humidity (\%) & 73.01 & 73.28 & 0.15 & ns \\
\hline Fat $(\%)$ & 2.89 & 2.69 & 0.09 & ns \\
\hline Protein (\%) & 23.12 & 23.06 & 0.13 & ns \\
\hline Ash (\%) & 0.97 & 0.96 & 0.01 & ns \\
\hline \multirow[t]{2}{*}{ Calcium (mg/100 g) } & 4.18 & 4.23 & 0.73 & ns \\
\hline & \multicolumn{3}{|c|}{ Physical trait } & \\
\hline $\mathrm{pH}$ & 5.68 & 5.62 & 0.02 & 0.02 \\
\hline Purge loss (\%) & 3.90 & 3.79 & 0.14 & ns \\
\hline Cooking loss (\%) & 23.37 & 23.44 & 0.35 & ns \\
\hline WBSF $\left(\mathrm{kg} \cdot \mathrm{cm}^{2-1}\right)$ & 3.18 & 2.97 & 0.07 & 0.03 \\
\hline
\end{tabular}

WBSF - Warner-Bratzler shear force.

\section{Discussion}

The higher ADG, together with the similar ADFI, explains the improvement in FCR. The lack of effect of dietary treatment on cattle behaviour during weighing operations and the calmer behaviour approaching the end of the fattening cycle, highlight a progressive adaptation to handling. This confirms that temperament and sensitivity to stressful events are essentially related to inherent genetic factors, as demonstrated by the moderate to high temperament heritability (Haskell et al., 2014).

The calmer behaviour in the pen of cattle fed CMA could be explained by the better buffering effect. Although the study was conducted on weathers, care has to be taken to extend the data to beef cattle. Commun et al. (2012) reported a more agitate and aggressive behaviour after acidosis challenge. The present results can thus be explained by the higher capability of CMA to buffer rumen pH, highlighted from the results of rumen $\mathrm{pH}$ at slaughter and the lower frequency of diseases related to acidosis such as bloat and not-traumatic lameness.

Blood glucose and lactic acid were high at day 21, while at day 100, a reduction was evident, with values within or close to the reference range (Jackson and Cockcroft, 2008). This was unexpected, considering that starch and energy content of the diet were higher at day 100, but can be explained by the adaptation to the finisher diet. In fact, stocking cattle such as those involved in the present trial are usually fed a small amount of concentrate and a diet with lower energy and protein content before being collected and transferred to the finishing farm. Moreover, stocker cattle imported from abroad to Italy experience feed restriction, as they are undergone, in a short period of time, to the collection from native farms, mixing in the sale yard or collection centres, and to long transport (Sgoifo Rossi et al., 2013). Feed restriction markedly reduces rumen functionality and microbial population (Fluharty et al., 1996). The increase in blood urea, which is the end product of protein metabolism, can be explained by the increase in dietary protein or to a small imbalance between energy and protein in the diet. 
Regarding the particle size of the undigested fraction, the higher fine residue found for CMA suggests an improvement in fibre degradation at the rumen level. The improvement in fibre and overall digestion, as highlighted from the faecal analysis and in vitro results, can be explained by the more effective buffer activity, as demonstrated by the higher rumen $\mathrm{pH}$ and reduction in $\mathrm{pH}$ fluctuation at the transition between the adaptation and finisher diet. However, the data related to rumen $\mathrm{pH}$ should just be taken as an indication due to the impossibility of determining the individual feed intake. Krajcarski-Hunt et al. (2002) found a decrease of in situ fibre digestion following sub-acute ruminal acidosis, likely due to the negative effect of the low $\mathrm{pH}$ on the microorganisms involved in fibre digestion. Mesgaran et al. (2010) reported a decrease in the Fibrobacter succinogenes population on in vitro models of acidotic diets, and even ciliate protozoa have been found to markedly decrease with rumen $\mathrm{pH}$ reduction (Nagaraja and Titgemeyer, 2007).

Regarding meat quality, $\mathrm{pH}$ is related to meat colour and texture traits. Indeed, a reduction in muscle $\mathrm{pH}$ increases the interaction between myofibrillar protein, improving light refraction and, therefore, determining a negative relationship between $\mathrm{pH}$ and meat colour (Abril et al., 2001). The difference in meat $\mathrm{pH}$ could be related to animal temperament. Fighting and competitive behaviours at the end of finishing can reduce muscle glycogen, thus limiting a decrease in $\mathrm{pH}$ after slaughter (Ponnampalam et al., 2017). Despite the known relationship between meat $\mathrm{pH}$ and tenderness, considering the narrow range of values found in the present study and the lack of abnormal $\mathrm{pH}$, it seems that other factors determined the difference in meat tenderness. Agitated behaviour in the days before slaughter can increase beef toughness: release of epinephrine following stress responses improves calpastatin activity, which impairs calpain activity (Gruber et al., 2010).

\section{Conclusions}

In beef cattle, diets with sodium bicarbonate can be effectively replaced with calcareous marine algae at an inclusion rate of $50 \%$ of the original sodium bicarbonate. This strategy improves growth rate, feed conversion, and fibre and total dry matter digestion. It reduces acidosis and related diseases, also promoting a calmer behaviour with beneficial effects on meat quality. The outcomes thus confirm the higher effectiveness of calcareous marine algae as a rumen buffer compared with sodium bicarbonate.

\section{Acknowledgments}

Authors are grateful to Celtic Sea Minerals for the financial support.

\section{References}

Abril, M.; Campo, M. M.; Önenç, A.; Sañudo, C.; Albertí, P. and Negueruela, A. I. 2001. Beef colour evolution as a function of ultimate pH. Meat Science 58:69-78. https://doi.org/10.1016/S0309-1740(00)00133-9

AOAC - Association of Official Analytical Chemists. 1990. Official methods of analysis. 15th ed. AOAC, Arlington, VA.

Canale, A.; Valente, M. E. and Ciotti, A. 1984. Determination of volatile carboxylic acids $\left(\mathrm{C}_{1}-\mathrm{C}_{5 i}\right)$ and lactic acid in aqueous acid extracts of silage by high performance liquid chromatography. Journal of the Science of Food and Agriculture 35:1178-1182. https://doi.org/10.1002/jsfa.2740351106

Comino, L.; Tabacco, E.; Righi, F; Revello-Chion, A.; Quarantelli, A. and Borreani, G. 2014. Effects of an inoculant containing a Lactobacillus buchneri that produces ferulate-esterase on fermentation products, aerobic stability, and fibre digestibility of maize silage harvested at different stages of maturity. Animal Feed Science and Technology 198:94-106. https://doi.org/10.1016/j.anifeedsci.2014.10.001

Commun, L.; Silberberg, M.; Mialon, M. M.; Martin, C. and Veissier, I. 2012. Behavioural adaptations of sheep to repeated acidosis challenges and effect of yeast supplementation. Animal 6:2011-2022. https://doi.org/10.1017/S1751731112001309

Cozzi, G.; Tessitore, E.; Contiero, B.; Ricci, R.; Gottardo, F. and Brscic, M. 2013. Alternative solutions to the concrete fully-slatted floor for the housing of finishing beef cattle: Effects on growth performance, health of the locomotor system and behavior. Veterinary Journal 197:211-215. https://doi.org/10.1016/j.tvjl.2013.03.001

Cruywagen, C. W.; Taylor, S.; Beya, M. M. and Caliz, T. 2015. The effect of buffering dairy cow diets with limestone, calcareous marine algae, or sodium bicarbonate on ruminal $\mathrm{pH}$ profiles, production responses, and rumen fermentation. Journal of Dairy Science 98:5506-5514. https://doi.org/10.3168/jds.2014-8875 
Cruywagen, C. W.; Swiegers, J. P.; Taylor, S. J. and Coetzee, E. 2004. The effect of Acid Buf in dairy cow diets on production response and rumen parameters. Journal of Dairy Science 87:46.

EU. 2006. Council Regulation (EC) No 1183/2006 of 24 July 2006 concerning the Community scale for the classification of carcasses of adult bovine animals. Official Journal of the European Union L 124:1-6.

Fluharty, F. L.; Loerch, S. C. and Dehority, B. A. 1996. Effects of feed and water deprivation on ruminal characteristics and microbial population of newly weaned and feedlot-adapted calves. Journal of Animal Science 74:465-474. https://doi.org/10.2527/1996.742465x

Grandin, T. 1993. Behavioural agitation during handling of cattle is persistent over time. Applied Animal Behavioural Science 36:1-9. https://doi.org/10.1016/0168-1591(93)90094-6

Gruber, S. L.; Tatum, J. D.; Engle, T. E.; Chapman, P. L.; Belk, K. E. and Smith, G. C. 2010. Relationships of behavioral and physiological symptoms of preslaughter stress to beef longissimus muscle tenderness. Journal of Animal Science 88:1148-1159. https://doi.org/10.2527/jas.2009-2183

Haskell, M. J.; Simm, G. and Turner, S. P. 2014. Genetic selection for temperament traits in dairy and beef cattle. Frontiers in Genetics 5:368. https://doi.org/10.3389/fgene.2014.00368

Jackson, P. and Cockroft, P. 2008. Clinical examination of farm animals. John Wiley \& Sons, Hobeken, NJ, USA.

Krajcarski-Hunt, H.; Plaizier, J. C.; Walton, J. P.; Spratt, R. and McBride, B. W. 2002. Short communication: Effect of subacute ruminal acidosis on in situ fiber digestion in lactating dairy cows. Journal of Dairy Science 85:570-573. https://doi.org/10.3168/jds.S0022-0302(02)74110-6

Krause, K. M. 2008. To buffer or not? Supplemental bicarb and subacute ruminal acidosis. In: Proceedings of the Southwest Animal Nutrition Conference, Tempe, AZ.

Lanier, J. L. and Grandin, T. 2002. The relationship between Bos taurus feedlot cattle temperament and foreleg bone measurements. Proceedings, Western Section, American Society of Animal Science 53:97-98.

McKiernan, W. A. 2007. Muscle scoring beef cattle. Primefact No. 328. NSW Department of Primary Industries, Orange, NSW.

Mesgaran, S. D.; Mousavi, A. H.; Arshami, J.; Vakili, A.; Ghovvati, S. and Jahani-Azizabadi, H. 2010. Effect of rumen acid load on in vitro ruminal total bacteria and Fibrobacter succinogenes populations determined by real-time PCR. Advances Animal Bioscience 1:294. https://doi.org/10.1017/S2040470010004371

Min, B. R.; Pinchack, W. E.; Fulford, J. D. and Puchala, R. 2005. Effect of feed additives on in vitro rumen characteristics and frothy bloat dynamics in steers grazing wheat pasture. Animal Feed Science and Technology 123-124:615-629. https://doi.org/10.1016/j.anifeedsci.2005.04.050

Nagaraja, T. G. and Titgemeyer, E. C. 2007. Ruminal acidosis in beef cattle: the current microbiological and nutritional outlook. Journal of Dairy Science 90:E17-E38. https://doi.org/10.3168/jds.2006-478

NRC - National Research Council. 2000. Nutrient requirements of beef cattle. Updated 7th edition. The National Academies Press, Washington, DC, USA.

Ponnampalam, E. N.; Hopkins, D. L.; Bruce, H.; Li, D.; Baldi, G. and Bekhit, A. E. D. 2017. Causes and contributing factors to "dark cutting" meat: Current trends and future directions: A review. Comprehensive Review in Food Science and Food Safety 16:400-430. https://doi.org/10.1111/1541-4337.12258

Russell, J. B. 1998. The importance of $\mathrm{pH}$ in the regulation of ruminal acetate to propionate ratio and methane production in vitro. Journal of Dairy Science 81:3222-3230. https://doi.org/10.3168/jds.S0022-0302(98)75886-2

Sgoifo Rossi, C. A.; Compiani, R; Baldi, G.; Vandoni, S. and Agovino, M. 2012. Effect of a source of sustained-release non-protein nitrogen on beef cattle. European Association of Animal Production (EAAP) 3rd Annual Meeting, Bratislava, Slovakia.

Sgoifo Rossi, C. A.; Compiani, R.; Baldi, G. and Bonfanti, M. 2013. Determination and assessment of BRD risk factors in newly received beef cattle. Large Animal Review 19:65-72.

Sgoifo Rossi, C. A. and Compiani, R. 2016. Ruminal acidosis of beef cattle and related diseases. Large Animal Review 22:273-279.

Spercher, D. J.; Hostetler, D. E. and Kaneene, J. B. 1997. A lameness scoring system that use posture and gait to predict dairy cattle reproductive performance. Theriogenology 47:1179-1187. https://doi.org/10.1016/S0093-691X(97)00098-8

Van Soest, P. J.; Robertson, J. B. and Lewis, B. A. 1991. Methods for dietary fiber, neutral detergent fiber and nonstarch polysaccharides in relation to animal nutrition. Journal of Dairy Science 74:3583-3597. https://doi.org/10.3168/jds.S0022-0302(91)78551-2

Wheeler, T. L.; Koohmaraie, M. and Shackelford, S. D. 1997. Effect of postmortem injection time and postinjection aging time on the calcium-activated tenderization process in beef. Journal of Animal Science 75:2652-2660. https://doi.org/10.2527/1997.75102652x 